\title{
Microbial Diversity in Drinking Water of Dishna City, Qena, Egypt and its Relation to Water Physico-Chemo Aspects
}

\author{
Rokaia B. Elamary ${ }^{1 *}$, Khaled A. Damarany ${ }^{2}$, Wesam M. Salem ${ }^{1}$, Waiel F. Sayed ${ }^{1}$ \\ ${ }^{1}$ Department of Botany and Microbiology, Faculty of Science, South Valley University, 83523 Qena, Egypt \\ ${ }^{2}$ Qena Company for Water and Wastewater. Holding Company of Water and Wastewater, Egypt
}

Received: 30 April 2021

Accepted: 18 July 2021

\begin{abstract}
The physical, chemical, or biological aspects of a water sample will generally comply with water quality guidelines or requirements to assess the consistency of the water for human use. Drinking water has been assessed monthly over the year 2019 for 6 vicinities in Dishna city such as Naga-Talha, Azaziyah, Safaruh, Alkhawla, Alsaeayida, and Nag-Abo-Elhamed. These places account for $50 \%$ of the drinking water supplying Dishna city. Aluminum content in all districts has crisis (5-17\%) where they have surpassed Qena Water Pollution Control Regulations on Drinking Water Quality and (30-140\%) of WHO (World Health Organization). Conductivity also exceeded WHO limits by 3-4\% in all districts during autumn except Alsaeayida district.

Microbiological parameters in some districts were also out of acceptable limits such as fecal coli and fecal streptococci in Naga talha and Naga aboelhamed respectively; total coli, fecal coli, and fecal streptococci in Azaziyaha. CCA (Canonical Corresponding Analysis) indicates that total algal count and microbial content were in positive correlation with all or some physicochemical parameters. Although almost all parameters examined for the Dishna drinking water samples were within the limits of the guidelines on drinking water quality of the World Health Organization and the Qena authorities> Water Pollution Control Regulation. However, some treatment processing should be concerned with some disturbing parameters. Seasonal water quality monitoring is also seen as a good practice for evaluating plants and processes for water treatment.
\end{abstract}

Keywords: drinking water quality assessment, microbiological parameters, physicochemical parameters, tap water

*e-mail: roka.elamary_88@yahoo.com 


\section{Introduction}

Water - one of the most important necessities and a basic element to human life survival - makes up over $71 \%$ of Earth's surface [1]. It is an increasingly stressed resource, is perceiving a worldwide increase in consumption, especially from the last four decades largely due to rising human population growth, socio-economic development, and changing consumer choices and trends [2]. The daily need for clean water is about $2 \mathrm{~L}$ for each person [3]. The supply of potable water is important to the development of any country [4]. Clean water is important for a safe population and contributes to the household >s quality of life by meeting basic water and sanitation needs. Poor quality water can cause social and economic damage as a result of water-related epidemics such as cholera, adequate wash could prevent the deaths of 361,000 children under the age of five or $5.5 \%$ of deaths in that age group [5]. The United Nations has assessed that at least 2.5 billion people in middle - and low-income countries lack access to enhanced hygiene and over 884 million lack access to improved drinking water [6]. About $3.1 \%$ of deaths occur due to the unhygienic and poor quality of water [7]. In public campgrounds, drinking water without treatment or filter-only treatment is unlikely to meet national requirements for human use, necessitating additional water treatment steps such as UV irradiation or chemical treatment [8]. Potable drinking water should be free from color, turbidity, odor, and microbes. It should be esthetically pleasant it must be free from unpleasant odors, so water must meet physicochemical and microbiological standards [9-11]. New strict regulations for water quality and water sources have been imposed in different countries. These regulations should ensure the protection of drinking water by eliminating or reducing dangerous substances in the water to a minimum concentration [12]. The guideline describes drinking water as water that is safe to drink for the rest of one's life, i.e., it poses no significant health risk. Researchers have been researching the safety of drinking water for a long time, around the world with rapid urbanization; the chemical aspects of water quality have become a cause of increasing concern as toxic chemicals in industrial Human wellbeing are jeopardized by effluents [13, 14]. Failure to ensure drinking-water safety may expose the community to the risk of outbreaks of intestinal and other infectious diseases. Increasing physicochemical constituents cause adverse health effects after prolonged periods of exposure, undrinkable water owing to improper taste, appearance, and odor. The greatest microbial hazards are associated with the ingestion of water that is contaminated with human or animal faces that is a source of pathogenic bacteria, protozoa, helminths, and viruses [15]. Therefore, there is a need to look for some useful indicators, both chemical and physical, which can be used to monitor both drinking water operation and performance [16]. Drinking water in each region presents varying degrees of health risk, for improving drinking-water quality so, periodic water quality monitoring and, use of simple, low-cost, and sustainable drinking-water treatment methods, such as boiling, solar disinfection, and chlorination [17]. Based on the fact that drinking water should be free of poisonous elements, living and non-living species, and an excessive amount of minerals, may be harmful to health. So, this study is concerned with the analysis of quality aspects of drinking water in Dishna distract for general water quality. Drinking water samples were analyzed for physio-chemical and biological properties for one year compared to the Egyptian standards for drinking water. All the results were analyzed to determine the seasonal variation in drinking water quality and determine to what extent the water was safe for human consumption.

\section{Materials and Methods}

\section{Study Site and Sampling}

In 6 districts of Dishna city, 72 water samples were gathered monthly during 2019 (12 samples for each district) after water flowed directly from taps for at least 5 minutes. Samples were collected in the morning between 9 am and 12 pm [18].

\section{Physico-Chemical Analysis}

Clean and high-density polyethylene vials were used to collect samples for physicochemical analysis. These bottles were rinsed 3-4 times with sample water after being washed with diluted hydrochloric acid. Water temperature and $\mathrm{pH}$ were recorded at the time of sample collection using a $\mathrm{pH}$ meter (HACH Sension 156, Loveland Co., USA). For total iron and manganese measurements, precipitation can be controlled in the sample containers by the addition of $1.5-3.0 \mathrm{ml}$ of concentrated $\mathrm{HNO} 3$ per liter of the sample immediately after collection. While, turbidity was determined by nephelometer (HACH 2100N, USA). Total dissolved solids (TDS) were determined by filtring $100 \mathrm{ml}$ sample through a $45 \mu \mathrm{m}$ glass fiber filter attached to the vacuum pump and weighing the filtrate. Electrical conductivity at $25^{\circ} \mathrm{C}$ was determined by using a $« \mathrm{HACH}$ Sension 156, Loveland Co., USA» conductivity meter. Total hardness, Alkalinity, and chlorides were determined using the EDTA titrimetric method and the indicators Eriochrome black $\mathrm{T}$ and murexide, respectively [19]. Nitrate, nitrite, ammonia, sulfate, and aluminum concentration were measured by spectrophotometer at $420 \mathrm{~nm}$ (HACH TUV, USA) and potassium nitrate for preparing the standard curve. Sodium, iron, zinc, copper, and manganese concentration were determined by atomic absorption spectroscopy (Varian AA240Z, Australia). A calibration curve was prepared by using at least three concentrations of standard metal 
solutions. Samples were prepared by digestion with $3 \mathrm{ml}$ concentrated $\mathrm{HNO}_{3}$. Then blank reagent (acidified deionized water) was introduced in the instrument followed by the sample. Total trihalomethanes and pesticides were determined by the GC System (VARIAN, Chromatography Systems Middelburg, The Netherlands). All physicochemical parameters were considered following APHA (2005) [19]. All parameters were compared with the limits of the Egyptian and WHO limits [20, 21].

\section{Microbiological Analysis}

In the sterile $1 \mathrm{~L}$ glass bottles, water samples used for microbiological testing have been obtained under aseptic conditions. Maintained in an icebox and then transported within 3 hours of sampling to a laboratory. Directly after the selection, samples were tested to mitigate bacterial population changes. All media and chemicals were supplied by Merck Co., England, prepared with deionized water, and autoclaved at $121^{\circ} \mathrm{C}$ for $15 \mathrm{~min}$ prior use. All microbiological indicators were determined according to APHA (2005) [19].

\section{Total Bacterial Count at Different Temperatures} $\left(35\right.$ and $22^{\circ} \mathrm{C}$ )

The media used were nutrient agar and buffer peptone water [19]. The sample volumes that were used were 1 and $0.1 \mathrm{ml}$. The sterile agar medium was melted and held at $44-46^{\circ} \mathrm{C}$ in a water bath until used. One set of three plates was set up for each temperature. The melted medium was mixed thoroughly with the sample in the plates by swirling. After being solidified, the plates were incubated for $48 \mathrm{~h}$ at $35^{\circ} \mathrm{C}$ and $72 \mathrm{~h}$ at $22^{\circ} \mathrm{C}$. At the end of incubation, the number of colonies developed on each plate was counted to determine the plate count as a colony-forming unit (CFU) per $\mathrm{ml}$ of sample.

\section{Determination of Total Coli, Fecal Coliform, and Fecal Streptococci of Water Samples by Membrane Filter Technique}

\section{Detection of Total Coliform}

Samples bottles were shaken vigorously and filtered through $45 \mu \mathrm{m}$ membrane filters. After that, the filter was placed on the M-Endo agar plate and incubated at $35^{\circ} \mathrm{C}$ for 22 to 24 hours. Coliform bacteria were described as red colonies with a metallic golden sheen after incubation. Picking two typical and two atypical colonies from a membrane filter with a sterile loop and placing them in lauryl tryptose broth tubes incubated at $35^{\circ} \mathrm{C}$ for 48 hours was used to verify both typical and non-typical coliform colonies. In brilliant green lactose broth (incubated at $35^{\circ} \mathrm{C}$ for 48 hours), tubes that generated gas were verified. Gas formation in lauryl tryptose broth and confirmed in brilliant green lactose broth within $48 \mathrm{~h}$ were verified as coliform culture.

\section{Detection of Fecal Coliform}

Detection of fecal coliform was carried out on M-FC medium with the same steps termed earlier on detection of total coliform. The plates were then incubated for $24 \mathrm{~h}$ at $44.5^{\circ} \mathrm{C}$. After incubation, colonies with blue color were counted as fecal coliform bacteria. In lauryl tryptose broth, typical and atypical fecal coliform colonies were confirmed, and gas output was verified in EC broth (tubes incubated at $44.5^{\circ} \mathrm{C}$ for 48 hours). The colony was identified as fecal coliform bacteria after gas was produced in lauryl tryptose broth and confirmed in EC within 48 hours.

\section{Detection of Fecal Streptococci}

Fecal streptococci were determined as described previously in total coliform but on $\mathrm{M}$ - Enterococcus agar and the plates were incubated for $48 \mathrm{~h}$ at $35^{\circ} \mathrm{C}$. After incubation, colonies with red colour were counted as fecal streptococci bacteria. All colonies that were red, maroon, or pink color were marked as typical colonies, which were confirmed by transferring the filtrate onto a plate of bile aesculinazid agar after sample filtration. The plates were incubated for 2 hours at $44^{\circ} \mathrm{C}$. Fecal streptococci colonies were identified by a tan to black color in the surrounding media [19].

\section{Algal Analysis, Its Toxins, and Detection of Rotifers, Nematodes, and Arthropoda}

Detection of total algae count rotifers, nematodes, and Arthropoda were detected as follows: One liter of water sample was taken in a container and pumped through a membrane filter. Then the container was rinsed with $1 \mathrm{~L}$ of filtered distilled water and pumped washings through the filter unit after water sample filtration to confirm there were no parasites on the surface of the water tank of the filtration unit. The filter was removed from the filter housing and placed into a suitable clean Petri dish containing a suitable amount of distilled water. The surface of the filter was scraped gently for $1 \mathrm{~min}$. the washings were Decanted into a $10 \mathrm{ml}$ centrifuge tube and centrifuged at $2000 \mathrm{rpm}$ for 15 min. The supernatant was genteelly and carefully aspirated off leaving the pellet. The obtained pellet was spread on a glass slide and examined on a compound microscope (OLYMPUS, CX31, Philippines) in a Sedgewick-Rafter Counting chamber after preservation in Lugol>s iodine [22]. Algal toxins were determined using High Performance Liquid Chromatography (HPLC) (Agilent Technology, 1260 Infinity, Germany) $[23,24]$. 


\section{Statistical Analysis}

The data were statistically managed to guess the mean from triplicates and Pearson's correlation analysis was used to determine the interactions among the bacterial indicators, algal count, and physic-chemical characteristics according to GraphPad Prism version 8. Differences were considered significant at $\mathrm{P}$ values of $\leq 0.05$ by the two-way analysis of variance ANOVA test. The microbial analyses and physicochemical characteristics of the investigated samples were subjected to canonical corresponding analysis (CCA) using the Canoco for Windows version 4.5 software. The positive correlation was expressed by a relatively long vector which roughly pointed into the same direction, whereas the arrow pointing into the opposite direction indicated a negative correlation.

\section{Result and Discussion}

Safe drinking water is a basic human right for all people because contaminated drinking water leads to the spread of diseases such as diarrhea, dysentery, cholera, and polio (WHO, 2018 b) [25]. To solve water and environmental problems, awareness and regular monitoring programs of water management and safe disposal of waste have been suggested (Amin et al., 2019) [26]. Understanding the factors inducing the quality of drinking water is necessary to get adequate decisions on the protection and management of drinking water quality. Dirican, 2015 [27] stated that continuous monitoring of physicochemical and microbial parameters is important to the management of water quality. The physicochemical parameters of water quality were listed in Table 1 . Water temperature varied from minimally of $22^{\circ} \mathrm{C}$ during winter to maximally $29.3^{\circ} \mathrm{C}$ during summer with slight variation between different districts. Water $\mathrm{pH}$ values ranged from 7.2 to 7.8 which was acceptable according to the Egyptian Standard Limits and WHO limits. Turbidity is one of the main detected physicochemical parameters. It may be present due to the occurrence of some suspended matters and microorganisms (Omer, 2019) [28]. The release of microorganisms or metals in distribution systems is also generally associated with turbidity events [29]. The acceptable limit of turbidity was $<1$ NTU (Chakrabarty and Sarama, 2011) [30]. The current study revealed that all samples were below the acceptable limits with a minimal value of 0.12 and maximally of 1.0 NTU (Table 1). Electrical conductivity reached its highest value of $312 \mu \mathrm{sm}^{-1}$ during autumn in Alkhawla district while the lowest value of $246 \mu \mathrm{s} \mathrm{cm}^{-1}$ was recorded during summer in more than one district. All samples have total dissolved solids values $\left(108-150 \mathrm{mgL}^{-1}\right)$ within the permissible limits. Alkalinity values were between 128 to $150 \mathrm{mgL}^{-1}$ while total hardness values were from 106 to $143 \mathrm{mgL}^{-1}$. All districts in Dishina city have acceptable

Table 1. Physico-chemical analysis of water samples in different districts of Dishna city.

\begin{tabular}{|c|c|c|c|c|c|c|c|c|c|c|c|c|c|}
\hline Dis. & Sea. & Tem. & $\mathrm{pH}$ & Tur. & Con. & TDS & Alk. & $\mathrm{TH}$ & $\mathrm{Cl}$ & $\mathrm{NO}_{3}$ & $\mathrm{NO}_{2}$ & $\mathrm{NH}_{3}$ & $\mathrm{SO}_{4}$ \\
\hline \multicolumn{2}{|c|}{ WHO limits } & --- & $6.5-8$ & 10 & 300 & 1000 & --- & 300 & 200 & 50 & 3 & $<0.2$ & 200 \\
\hline \multicolumn{2}{|c|}{ Egy. limits } & --- & $6.5-8.5$ & 1 & --- & 1000 & --- & 500 & 250 & 45 & 0.2 & 0.5 & 250 \\
\hline \multirow{4}{*}{ Naga-Talha } & Win. & 22 & 7.4 & 0.37 & 270 & 137 & 138 & 143 & 18 & 0.37 & 0.03 & 0.03 & 22 \\
\hline & Spr. & 23.5 & 7.8 & 0.72 & 246 & 123 & 146 & 127 & 17 & 0.33 & 0.03 & 0.03 & 20 \\
\hline & Sum. & 29.3 & 7.5 & 0.73 & 248 & 108 & 145 & 106 & 14 & 0.31 & 0.02 & 0.03 & 18 \\
\hline & Aut. & 27.7 & 7.2 & 0.12 & $308^{*}$ & 149 & 128 & 118 & 18 & 0.29 & 0.02 & 0.03 & 17 \\
\hline \multirow{4}{*}{ Azaziyah } & Win. & 22 & 7.6 & 0.51 & 267 & 134 & 136 & 143 & 17 & 0.35 & 0.03 & 0.03 & 21 \\
\hline & Spr. & 23.5 & 7.4 & 0.56 & 246 & 124 & 146 & 127 & 17 & 0.32 & 0.03 & 0.03 & 20 \\
\hline & Sum. & 29.2 & 7.4 & 0.57 & 250 & 108 & 148 & 107 & 14 & 0.32 & 0.02 & 0.03 & 18 \\
\hline & Aut. & 27.7 & 7.3 & 0.27 & $309^{*}$ & 148 & 128 & 117 & 17 & 0.28 & 0.02 & 0.03 & 17 \\
\hline \multirow{4}{*}{ Safaruh } & Win. & 22 & 7.4 & 0.51 & 267 & 135 & 139 & 143 & 17 & 0.35 & 0.03 & 0.02 & 22 \\
\hline & Spr. & 23.5 & 7.3 & 0.9 & 248 & 123 & 149 & 127 & 16 & 0.32 & 0.03 & 0.03 & 20 \\
\hline & Sum. & 29.2 & 7.3 & 0.5 & 248 & 109 & 149 & 106 & 15 & 0.31 & 0.02 & 0.03 & 17 \\
\hline & Aut. & 27.7 & 7.3 & 0.35 & $310^{*}$ & 149 & 130 & 120 & 17 & 0.28 & 0.02 & 0.03 & 17 \\
\hline \multirow{4}{*}{ Alkhawla } & Win. & 22 & 7.5 & 1.0 & 272 & 136 & 139 & 141 & 17 & 0.34 & 0.03 & 0.03 & 21 \\
\hline & Spr. & 23.5 & 7.3 & 0.58 & 248 & 124 & 148 & 131 & 16 & 0.33 & 0.03 & 0.03 & 21 \\
\hline & Sum. & 29 & 7.3 & 0.57 & 248 & 108 & 148 & 108 & 14 & 0.30 & 0.02 & 0.03 & 19 \\
\hline & Aut. & 27.7 & 7.3 & 0.28 & $312 *$ & 147 & 129 & 120 & 16 & 0.28 & 0.02 & 0.03 & 17 \\
\hline
\end{tabular}


Table 1. Continued.

\begin{tabular}{|c|c|c|c|c|c|c|c|c|c|c|c|c|c|}
\hline \multirow{4}{*}{ Alsaeayid } & Win. & 22 & 7.5 & 0.7 & 268 & 136 & 138 & 140 & 18 & 0.34 & 0.03 & 0.03 & 21 \\
\hline & Spr. & 23.5 & 7.3 & 0.75 & 246 & 123 & 150 & 130 & 16 & 0.34 & 0.03 & 0.03 & 21 \\
\hline & Sum. & 29 & 7.4 & 0.65 & 249 & 109 & 146 & 107 & 14 & 0.32 & 0.02 & 0.02 & 19 \\
\hline & Aut. & 27.7 & 7.4 & 0.21 & 286 & 149 & 131 & 117 & 18 & 0.28 & 0.02 & 0.03 & 17 \\
\hline \multirow{4}{*}{ N.aboelh } & Win. & 22 & 7.5 & 0.33 & 270 & 137 & 139 & 140 & 19 & 0.37 & 0.03 & 0.02 & 21 \\
\hline & Spr. & 23.5 & 7.4 & 0.57 & 246 & 123 & 149 & 129 & 17 & 0.3 & 0.03 & 0.04 & 21 \\
\hline & Sum. & 28.8 & 7.4 & 0.67 & 249 & 110 & 148 & 108 & 15 & 0.33 & 0.02 & 0.03 & 19 \\
\hline & Aut. & 27.7 & 7.4 & 0.24 & $310^{*}$ & 150 & 128 & 119 & 17 & 0.29 & 0.02 & 0.03 & 17 \\
\hline Dis. & Sea. & $\mathrm{Al}$ & $\mathrm{RCl}$ & $\mathrm{Mn}$ & $\mathrm{Cu}$ & $\mathrm{Zn}$ & $\mathrm{Na}$ & $\mathrm{Fe}$ & THM & $\mathrm{ClF}$ & $\mathrm{DC}$ & DB & $\mathrm{BrF}$ \\
\hline \multicolumn{2}{|c|}{ WHO limits } & 0.1 & --- & 0.4 & 2 & 5 & 200 & 0.3 & 1 & 0.3 & 0.06 & 0.1 & 0.1 \\
\hline \multicolumn{2}{|c|}{ Egy. limits } & 0.2 & $<5$ & 0.4 & 2 & 3 & 200 & 0.3 & 0.1 & 0.3 & 0.06 & 0.06 & 0.1 \\
\hline \multirow{4}{*}{ Naga-Talha } & Win. & $0.23 *$ & 1.1 & 0.01 & 0.003 & 0.01 & 20 & 0.07 & 0.03 & 0.02 & 0.005 & 0.01 & 0.003 \\
\hline & Spr. & $0.22 *$ & 1.4 & 0.01 & 0.003 & 0.01 & 20 & 0.04 & 0.01 & 0.01 & 0.003 & 0.01 & 0.003 \\
\hline & Sum. & $0.2^{*}$ & 1.4 & 0.02 & 0.004 & 0.01 & 19 & 0.03 & 0.05 & 0.03 & 0.006 & 0.04 & 0.002 \\
\hline & Aut. & $0.13^{*}$ & 1.9 & 0.02 & 0.003 & 0.01 & 20 & 0.05 & 0.02 & 0.01 & 0.003 & 0.01 & 0.002 \\
\hline \multirow{4}{*}{ Azaziyah } & Win. & $0.21^{*}$ & 1.2 & 0.01 & 0.003 & 0.01 & 20 & 0.07 & 0.03 & 0.02 & 0.002 & 0.016 & 0.003 \\
\hline & Spr. & $0.24 *$ & 1.5 & 0.01 & 0.003 & 0.01 & 20 & 0.04 & 0.004 & 0.02 & 0.002 & 0.005 & 0.002 \\
\hline & Sum. & $0.24 *$ & 1.6 & 0.01 & 0.003 & 0.01 & 19 & 0.03 & 0.06 & 0.03 & 0.004 & 0.014 & 0.002 \\
\hline & Aut. & $0.14^{*}$ & 1.7 & 0.01 & 0.004 & 0.01 & 20 & 0.05 & 0.02 & 0.01 & 0.003 & 0.005 & 0.002 \\
\hline \multirow{4}{*}{ Safaruh } & Win. & $0.22 *$ & 1.1 & 0.01 & 0.002 & 0.01 & 20 & 0.06 & 0.02 & 0.02 & 0.004 & 0.012 & 0.003 \\
\hline & Spr. & $0.23 *$ & 1.6 & 0.01 & 0.002 & 0.01 & 20 & 0.03 & 0.004 & 0.01 & 0.003 & 0.005 & 0.003 \\
\hline & Sum. & $0.2^{*}$ & 1.5 & 0.01 & 0.003 & 0.01 & 19 & 0.04 & 0.04 & 0.03 & 0.004 & 0.013 & 0.003 \\
\hline & Aut. & $0.15^{*}$ & 2 & 0.02 & 0.003 & 0.01 & 20 & 0.06 & 0.02 & 0.01 & 0.004 & 0.006 & 0.002 \\
\hline \multirow{4}{*}{ Alkhawla } & Win. & $0.2^{*}$ & 1.1 & 0.01 & 0.003 & 0.01 & 20 & 0.07 & 0.02 & 0.02 & 0.004 & 0.012 & 0.002 \\
\hline & Spr. & $0.22 *$ & 1.6 & 0.01 & 0.004 & 0.01 & 20 & 0.04 & 0.004 & 0.02 & 0.003 & 0.007 & 0.003 \\
\hline & Sum. & $0.21 *$ & 1.3 & 0.02 & 0.003 & 0.01 & 19 & 0.03 & 0.05 & 0.03 & 0.003 & 0.009 & 0.006 \\
\hline & Aut. & $0.14^{*}$ & 2 & 0.02 & 0.004 & 0.01 & 20 & 0.06 & 0.02 & 0.02 & 0.004 & 0.004 & 0.002 \\
\hline \multirow{4}{*}{ Alsaeayid } & Win. & $0.2^{*}$ & 1.1 & 0.01 & 0.004 & 0.01 & 20 & 0.06 & 0.03 & 0.02 & 0.003 & 0.008 & 0.003 \\
\hline & Spr. & $0.2 *$ & 1.4 & 0.02 & 0.003 & 0.01 & 20 & 0.04 & 0.007 & 0.02 & 0.005 & 0.009 & 0.002 \\
\hline & Sum. & $0.21 *$ & 1.4 & 0.02 & 0.003 & 0.01 & 19 & 0.04 & 0.05 & 0.03 & 0.009 & 0.011 & 0.004 \\
\hline & Aut. & $0.16^{*}$ & 1.9 & 0.02 & 0.003 & 0.01 & 20 & 0.05 & 0.02 & 0.02 & 0.004 & 0.003 & 0.003 \\
\hline \multirow{4}{*}{ N.aboelh. } & Win. & $0.22 *$ & 1.2 & 0.01 & 0.003 & 0.01 & 20 & 0.07 & 0.03 & 0.02 & 0.003 & 0.01 & 0.004 \\
\hline & Spr. & $0.21^{*}$ & 1.6 & 0.02 & 0.003 & 0.01 & 20 & 0.05 & 0.005 & 0.01 & 0.004 & 0.01 & 0.003 \\
\hline & Sum. & $0.22 *$ & 1.4 & 0.02 & 0.004 & 0.01 & 19 & 0.04 & 0.05 & 0.03 & 0.007 & 0.01 & 0.004 \\
\hline & Aut. & $0.16^{*}$ & 2 & 0.02 & 0.004 & 0.01 & 20 & 0.05 & 0.02 & 0.01 & 0.007 & 0.003 & 0.003 \\
\hline
\end{tabular}

Physico-chemical parameters of water samples in 6 districts of Dishna city compared with WHO and Egyptian limits. The districts named Naga-Talha, Azaziyah, Safaruh, Alkhawla, Alsaeayida, Naga abo elhamed during the four seasons. Temp.- temperature; Cond.- conductivity; Alk. -alkalinity; Turbi- turbidity; TH.- total hardness; TDS- total dissolved solids; R. Cl- Residual chlorine; THM- total halomethanes; ClF-chloroform; DC-di chlorobromomethane; DB- dibromochloromethane; BrF-bromoform. *: means values exceeded the permissible limits. Note: Temperature in ${ }^{\circ} \mathrm{C}$, turbidity in unites, $\mathrm{EC}$ in $\mu \mathrm{S} / \mathrm{cm}$ and all concentrations of chemical elements in $\mathrm{mg} / \mathrm{L}$. 
limits of chloride with values of $14-19 \mathrm{mgL}^{-1}$. Nitrate and nitrite in the examined samples were also within the permissible limits with concentrations ranged from 0.28 to $0.37 \mathrm{mgL}^{-1}$ and 0.02 to $0.03 \mathrm{mgL}^{-1}$, respectively. Although the presence of ammonia in drinking water has not associated with health effects, it may lead to the formation of nitrite that causes failure in manganese removal (Khalil et al., 2013) [18]. In the current study, ammonia and sulfate concentrations ranged from $0.02-0.03$ and $17-22 \mathrm{mgL}^{-1}$, respectively which is lower than the permissible limits (Table 1).

Aluminum pollution of treatment water has been a source of concern for several years (Van Benschoten and Edzwald, 1990) [31]. This is due to the fact that acid rain has raised the aluminum level in many freshwater sources (Sivaramanan, 2015) [32]. Also, its high level gives rise to turbidity and decreases disinfection efficiency (M Mohamed et al. 2020) [33]. Furthermore, excessive aluminum intake may cause neuromuscular effects [34, 35]. The acceptable limit of aluminum according to Egyptian Standard Limits according to the minister of Health decision no. 458 (2007) and WHO were 0.2 and $0.1 \mathrm{mgl}^{-1}$, respectively. The current study revealed a high level of aluminum in all studied Dishna districts in all seasons (0.13-0.24 $\left.\mathrm{mgL}^{-1}\right)$ (Table 1).

Residual chlorine level was within the acceptable limits $(<5)$ where its level in all districts was between 1.1 and 2. Manganese and copper concentrations in drinking water in the current study were below (0.01-0.02 and $0.003-0.004 \mathrm{mgL}^{-1}$ respectively) the legislation values $\left(0.4\right.$ and $2 \mathrm{mgL}^{-1}$ for manganese and copper, respectively). Zinc, sodium, and iron levels were also below the enactment limits of the Egyptian ministry of health and WHO standards as stated in Table 1. Where zinc concentration was $0.01 \mathrm{mgL}^{-1}$. Sodium and iron concentrations were 19-20 and 0.03-0.07 $\mathrm{mgL}^{-1}$, respectively. The standard limits were $3,200,0.3 \mathrm{mgL}^{-1}$, respectively.

Trihalomethanes (THMs) are formed in drinking water primarily as a consequence of the chlorination of organic matter existing in raw water supplies. The rate of

THM formation is affected by the concentrations of chlorine and humic acid, as well as temperature, $\mathrm{pH}$, and bromide ions [36, 37]. Cotruvo and Amato (2019) [38], found that increasing the duration of exposure to THMs increases bladder and lung cancer risk. THMs levels in the current study in all districts (0.004-0.06) were below the permissible limits $\left(0.1 \mathrm{mgL}^{-1}\right)$ over the year.

Chloroform (also called trichloromethane) is the most important THMs in drinking water, it is a chemical used to make other chemicals and a byproduct of chlorinating water (MDH, 2016) [39]. Its high levels in drinking water for a long time cause damage to kidney and liver cancer (Aslani et al., 2019) [40]. Dishina city has acceptable limits of chloroform (0.01-0.03 $\left.\mathrm{mgL}^{-1}\right)$. Dibromochloromethane (DBCM) is an intermediate in the manufacture of refrigerants, pesticides, propellants, and other organic chemicals, while bromodichloromethane (BDCM) is toxic disinfection byproducts results from elevated chloride and bromide contents in supply waters during chlorine disinfection [41]. In an NTP bioassay, DBCM induced hepatic tumors in female and possibly in male mice but not in rats and cardiotoxicity. Bromoform is used in the synthesis of pharmaceuticals, as a solvent, and as an ingredient in fire-resistant chemicals and gauge fluid in the aircraft and shipbuilding industries. BDCM and bromoform were considered to be fetotoxic, based on the observation of interparietal anomalies. As listed in Table 1, BDCM, DBCM, and bromoform concentrations (0.002-0.009, 0.003-0.016, and 0.002-0.006 $\mathrm{mgL}^{-1}$, respectively) were below the acceptable limits $(0.06$, 0.06 , and $0.1 \mathrm{mgL}^{-1}$, respectively).

The results obtained in Table 2 illustrate that the total bacterial count at 35 and $22^{\circ} \mathrm{C}$ in all districts (0-37, and 0-43 cell/ $\mathrm{ml})$ were below the acceptable limits $(50 \mathrm{cell} / \mathrm{ml})$. Fecal contamination is considered a significant danger to human health [42]. A large number of pathogens could be transmitted to humans through contaminated water with fecal matter such as Salmonella, Shigella, Pseudomonas aeruginosa, multicellular parasites enteroviruses, Aeromonas hydrophila, and Vibrio parahaemolyticus [43]. Luckily, determining coliform bacteria (total and/or fecal coliforms consider an indirect attitude to quantifying fecal contamination [44-46]. The results of the current study as listed in Table 2, indicate that the total coliform count was below the permissible limits $(\leq 2)$ except during autumn in Azaziyah bacterial count exceeds Egyptian ministry health and WHO limits by 5 fold. Fecal coliform count in Dishina city was also below the permissible limits $(<1)$ except during summer in Naga-Talha and during autumn in Azaziyah by one fold. Finally, fecal Streptococcus count exceeds limits during autumn in Azaziyah by one fold Table 2 where the acceptable limit was $<1$.

Algal removal is an important measure of the treatment efficiency since algae especially those belonging to blue-green algae are in interest to water treatment authorities due to their production. The presence of toxic cyanobacteria in surface waters, such as Microcystis, Anabaena, Oscillatoria, and Nostoc organisms, and their effect on drinking water treatment plants (WTPs), is a global concern (Zamyadi et al., 2021) [47], Since potentially harmful cyanobacteria, have been found in the numbers in water supply systems around the world in recent years, they pose a health risk. (Zamyadi et al., 2009) [48]. Alarming levels of water contamination are detrimental to the marine environment, resulting in a significant loss in species diversity. Diatoms have a high ability to live in polluted water sources, making them compelling bioindicators for effectively monitoring changes in environmental matrices (Saxena et al., 2020). [49]. The current study revealed a high level of total and blue-green algae in all studied Dishna districts (74-221 organism/ml) (Table 2). 
Table 2. Microbiological and algal analysis of water samples in different districts of Dishna city.

\begin{tabular}{|c|c|c|c|c|c|c|c|}
\hline Districts & Season & $\mathrm{T} 35^{\circ} \mathrm{C}$ & T $22{ }^{\circ} \mathrm{C}$ & $\mathrm{T}$ coli & F coli & F strep. & $\mathrm{T}$ algae \\
\hline \multicolumn{2}{|c|}{ WHO limits } & ------- & ------- & 0 & 0 & 0 & ---- \\
\hline \multicolumn{2}{|c|}{ Egyptian limits } & 50 & 50 & $\leq 2$ & 0 & 0 & ----- \\
\hline \multirow{4}{*}{ Naga-Talha } & Winter & 3 & 2 & 1 & 0 & 0 & 106 \\
\hline & Spring & 2 & 2 & 2 & 0 & 0 & 97 \\
\hline & Summer & 3 & 2 & 0 & $2 *$ & 0 & 164 \\
\hline & Autumn & 3 & 12 & 2 & 0 & 0 & 110 \\
\hline \multirow{4}{*}{ Azaziyaha } & Winter & 4 & 6 & 0 & 0 & 0 & 119 \\
\hline & Spring & 4 & 1 & 0 & 0 & 0 & 75 \\
\hline & Summer & 2 & 3 & 0 & 0 & 0 & 221 \\
\hline & Autumn & 37 & 43 & $11 *$ & $3 *$ & $2 *$ & 85 \\
\hline \multirow{4}{*}{ Safaruh } & Winter & 3 & 3 & 0 & 0 & 0 & 128 \\
\hline & Spring & 1 & 1 & 0 & 0 & 0 & 74 \\
\hline & Summer & 2 & 1 & 0 & 0 & 0 & 234 \\
\hline & Autumn & 7 & 1 & 0 & 0 & 0 & 111 \\
\hline \multirow{4}{*}{ Alkhawla } & Winter & 2 & 2 & 0 & 0 & 0 & 122 \\
\hline & Spring & 2 & 0 & 0 & 0 & 0 & 75 \\
\hline & Summer & 1 & 1 & 0 & 0 & 0 & 171 \\
\hline & Autumn & 2 & 2 & 0 & 0 & 0 & 114 \\
\hline \multirow{4}{*}{ Alsaeayida } & Winter & 3 & 1 & 0 & 0 & 0 & 150 \\
\hline & Spring & 3 & 0 & 0 & 0 & 0 & 79 \\
\hline & Summer & 1 & 1 & 0 & 0 & 0 & 192 \\
\hline & Autumn & 7 & 2 & 0 & 0 & 0 & 118 \\
\hline \multirow{4}{*}{ N. aboelhamed } & Winter & 4 & 2 & 0 & 0 & 0 & 190 \\
\hline & Spring & 2 & 1 & 0 & 0 & $1 *$ & 104 \\
\hline & Summer & 1 & 0 & 0 & 0 & 0 & 210 \\
\hline & Autumn & 0 & 3 & 0 & 0 & 0 & 114 \\
\hline
\end{tabular}

Microbiological and algal analysis of water samples in 6 districts of Dishna city, they named Naga-Talha, Azaziyah, Safaruh, Alkhawla, Alsaeayida, Naga abo elhamed during the four seasons. $\mathrm{T} 35^{\circ} \mathrm{C}$ and T $22{ }^{\circ} \mathrm{C}$-total bacterial count at 35 and $22^{\circ} \mathrm{C}$ expressed in cell $/ \mathrm{cm}^{3}$; T coli- total coli; F coli- fecal coliform; F strep. - fecal streptococci; T algae-total algae; *: means values exceeded the permissible limits of WHO and Egyptian limits.

Several species of algae produce stronger lethally toxins, that were frequently released into the water when the cells of toxic algae rupture or die. The Presence of significant quantities of toxic algae in the water or if their toxin is swallowed, posing a health risk to humans (Safiyanu et al., 2018) [50]. Toxic algae kill fishes and animals and make people sick. They are probably signs that the health of ecologically important and commercially valuable bays, estuaries, and freshwater environment is deteriorating (Carmichae, 1994) [51]. Interestingly, algal toxins were absent in all examined samples all over Dishina city.

The presence of free-living nematodes in drinking water does not always mean a direct risk to human health. Water suppliers have largely regarded it as an aesthetic problem, either directly or by their association with discoloured water (WHO, 2004) [52]. Drinking water containing high concentrations of nematodes has been documented to have an unpleasant taste. Interestingly, Rotifers, nematodes, and Arthropoda were absent in the targeted samples. It has been found that all samples are free of rotifers, Arthropoda, and nematodes except for some samples of the outlet, it is found that they contain live nematodes.

In general statistical analysis of the interrelationships between microbiological analysis and physicochemical parameters using Canonical correlation analysis (CCA) correlations were introduced in Fig. 1. 

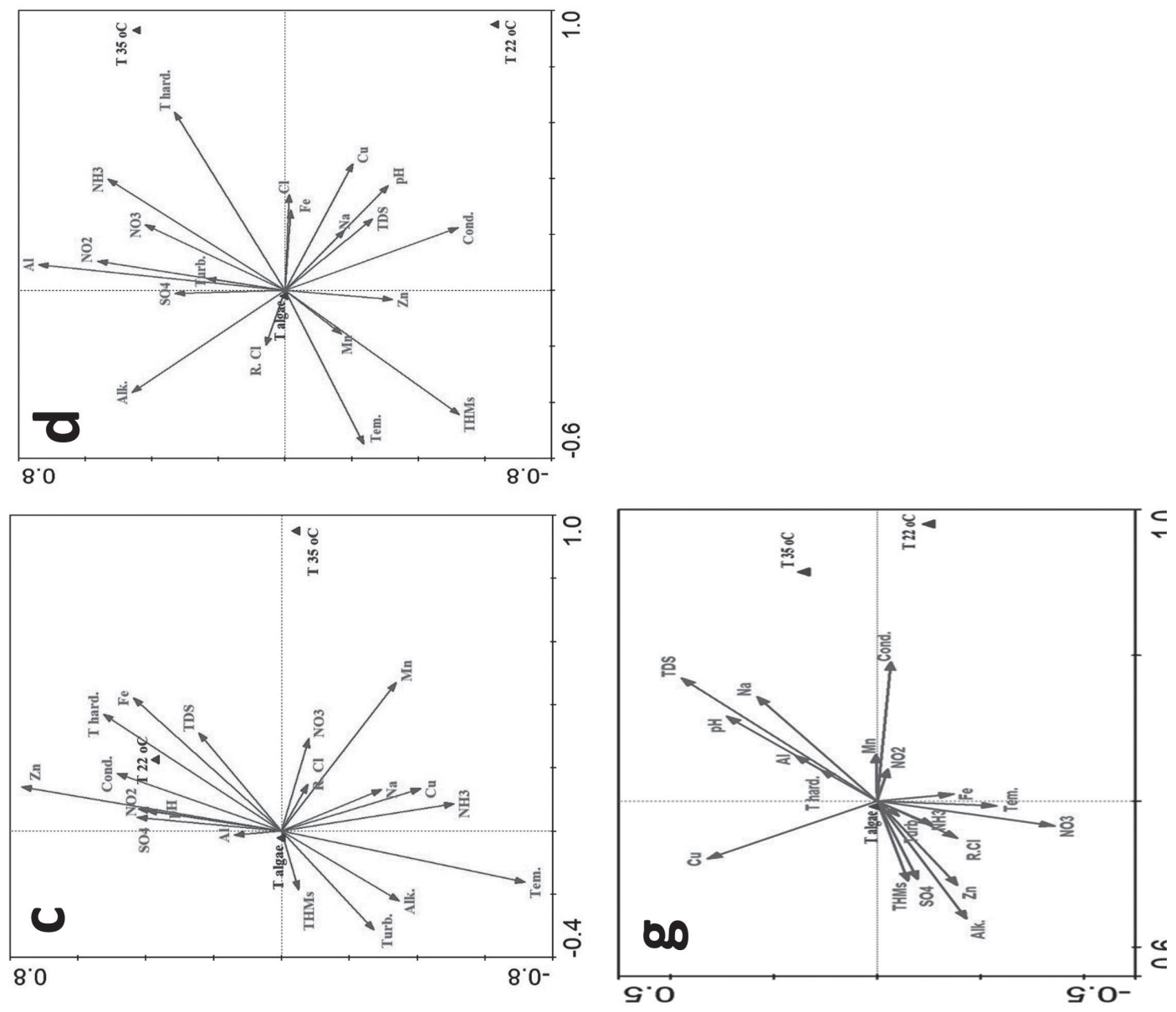

过

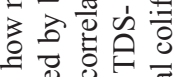

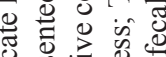

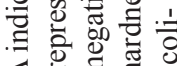

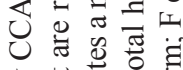

石要

च

㐘 春

品

a

की कै

要品 응.

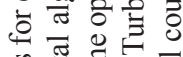

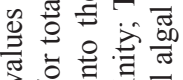

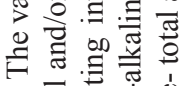

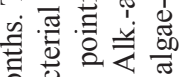

욤ำ

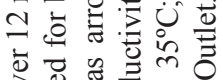

व

苋呟

ฮั

毒

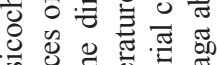

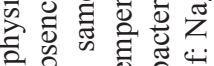
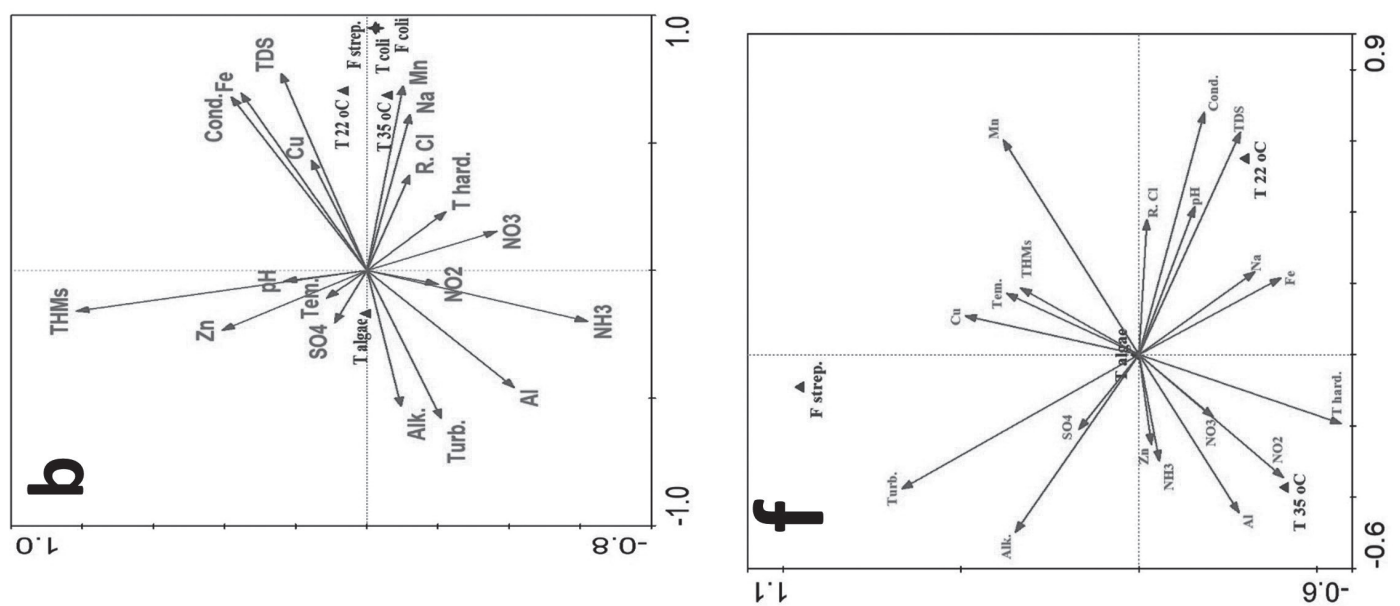

西要需

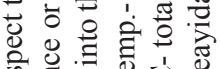

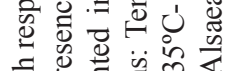

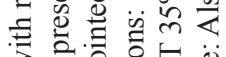

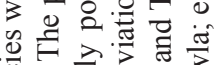

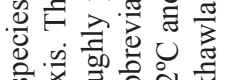

क.

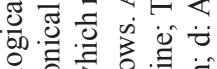

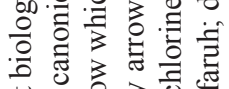

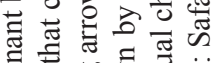

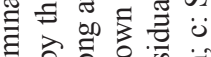

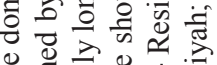

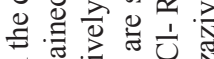
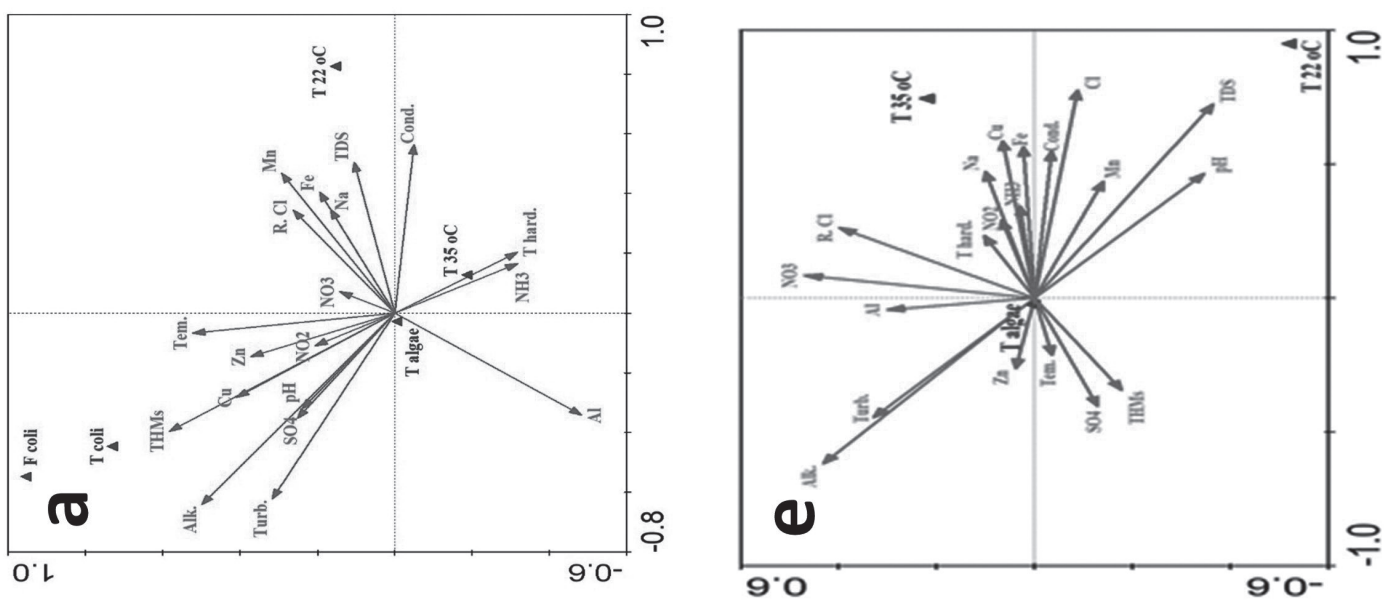

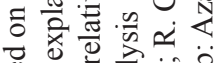

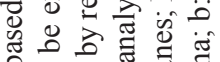

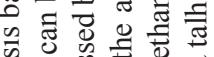

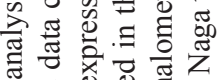

ส

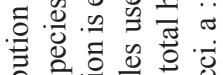

की की

㝵

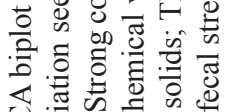

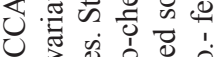

- o $\frac{0}{00} 00$

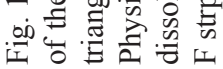


The CCA biplot summarizes the results and shows the correlation between physicochemical variables, and the correspondence of bacterial and/or total algal species count. Samples were plotted in different areas of the diagram depending on their environmental characteristics. The CCA method creates an ordination diagram in which the axes are made up of a variety of environmental variables [53]. In Nag talha district (Fig. 1a), the correlation between biological species, and environmental data was explained by two axes. Both axes shows the highest positive correlation among a wide number of physicochemical variables that have a role in the increasing Fecal coli and Total coli such as Temp., THMs, Alk., Turbidity, pH, $\mathrm{Zn}, \mathrm{Cu}$, and $\mathrm{SO}_{4}$. On the other hand, a low positive correlation was observed in presence of $\mathrm{NO}_{2}$. Total algal count in Nag talha district showed a high positive correlation with Al while, $\mathrm{T} 35^{\circ} \mathrm{C}$ were highly correlated with $\mathrm{NH}_{3}$, T hard, and Cond. Finally, $\mathrm{T} 22^{\circ} \mathrm{C}$ exhibited the highest positive correlation with $\mathrm{Mn}$, TDS, Fe, R. $\mathrm{Cl}$, and $\mathrm{Na}$ while a low correlation was detected in presence of $\mathrm{NO}_{3}$.

Azaziyah plant was visualized in Fig. 1b), The right-hand portion of the first axis was predominantly occupied by Fecal streptococci, Fecal coli, Total coli, total bacterial count at 22 and $35^{\circ} \mathrm{C}$ and affected positively by (TDS, Cond, $\mathrm{T}$ hard. $\mathrm{NO}_{3}, \mathrm{Na}, \mathrm{Cu}, \mathrm{Fe}$, $\mathrm{Mn}$, and $\mathrm{R} . \mathrm{Cl}$ ). The distribution of algae was positively correlated to some variables including THMs, Turb. Alk, $\mathrm{NH}_{3} . \mathrm{NO}_{2}, \mathrm{SO}_{4}, \mathrm{pH}$, Temp., $\mathrm{Al}$ and $\mathrm{Zn}$ ). It is worth mention, the distribution of Fecal strep, $\mathrm{T}$ coli, and $\mathrm{F}$ coli with some physico chemical parameters mentioned above affect negatively on the physicochemical parameters for the distribution of total algae (parameters on the left-hand side). Fig. 1c) envisage Safaruh district, the dispersal of the total algal count was positively correlated with all physicochemical parameters while $\mathrm{T}$ 35 and $\mathrm{T} 22^{\circ} \mathrm{C}$ were positively correlated with $\left(\mathrm{NO}_{3}, \mathrm{R}\right.$. $\mathrm{Cl}, \mathrm{NH}_{3}, \mathrm{Na}, \mathrm{Cu}$, and $\mathrm{Mn}$ ) and (TDS, Fe, Cond, Thard. $\mathrm{NO}_{2}, \mathrm{pH}$, and $\mathrm{SO}_{4}$ ), respectively.

In alkhawla plant (Fig. 1d), the total algal count was highly correlated with all physicochemical variables such as Alk., $\mathrm{NH}_{3}, \mathrm{NO}_{3}, \mathrm{NO}_{2}, \mathrm{pH}$, Cond, T hard. TDS, Temp., THMs, Turb., R.Cl, and some heavy metals: $\mathrm{Fe}, \mathrm{Al}, \mathrm{Cu}, \mathrm{Mn}, \mathrm{Zn}, \mathrm{Na}, \mathrm{Cl}$, and $\mathrm{SO}_{4}$. In contrast, the right-hand portion of the first axis was predominantly occupied by the total bacterial count at 22 and $35^{\circ} \mathrm{C}$ and affected positively by $\mathrm{T}$ hard., $\mathrm{NH}_{3}, \mathrm{NO}_{3}, \mathrm{NO}_{2}$, Turbi. and $\mathrm{Al}$ for $\mathrm{T} 35^{\circ} \mathrm{C}$ while, $\mathrm{T} 22^{\circ} \mathrm{C}$ was affected by $\mathrm{pH}$, cond, TDS, $\mathrm{Cu}, \mathrm{Na}, \mathrm{Fe}$ and $\mathrm{Cl}$. Fig. 1e) pictures Alsaeayida plant, the total algal count showed positive correlations with approximately all physicochemical parameters on, the other hand, $\mathrm{T} 22^{\circ} \mathrm{C}$ and $\mathrm{T} 35^{\circ} \mathrm{C}$ were positively affected by (TDS, $\mathrm{pH}, \mathrm{Cl})$ and $\left(\mathrm{NO}_{3}, \mathrm{R} . \mathrm{Cl}\right.$, $\mathrm{Cu}, \mathrm{Na}, \mathrm{Fe}$ ), respectively. Finally, Nag abo elhamed district Fig. 1f), all parameters affect positively ( $\mathrm{T}$ algae), while Fecal streptococci were distributed in the presence of Turb, Alk., and $\mathrm{SO}_{4} ; \mathrm{T}_{2}{ }^{\circ} \mathrm{C}$ appeared when Cond. and TDS as major factors and $\mathrm{pH}, \mathrm{R} . \mathrm{Cl}$. $\mathrm{Na}, \mathrm{Fe}$ have a slight role. For $\mathrm{T} 35^{\circ} \mathrm{C} \mathrm{T}$ hard, $\mathrm{NO}_{2}, \mathrm{NO}_{3}$,
$\mathrm{NH}_{3}, \mathrm{Al}$, and $\mathrm{Zn}$. Fig. 1g) represents an outlet that is approximately the same as Alkhawla, Alsaeayidea, and Safurah plants. In general, total algae and heterotrophic bacteria are the most predominant in all samples.

\section{Conclusions}

From all the above results we can conclude that the obtained water from the six locations samples can be considered not safe water for drinking purposes depending on its physicochemical and biological properties in comparison to the decision of the Ministry of Health, 458 for (2007) concerning drinking water and WHO. Although most detected parameters did not exceed the values set by the Ministry of Health decision and the exception for some parameters, but suitable treatments are required to deal with the disturbing parameters.

\section{Conflict of Interest}

The authors declare that they have no conflict of interest.

\section{References}

1. MOORE, SHORB J., PRAT-RESINA X., TIM WENDORFF E. V., JOHN W., HAHN A. (2020, August 18). Water on Earth. Retrieved April 20, 2021, from https:// chem.libretexts.org/@go/page/50825.

2. WWDR (The United Nations World Water Development. The United Nations World Water Development report; leaving no one behind. https://unesdoc.unesco.org/ ark:/48223/pf0000367306, 2019.

3. YASSI A., KJELLSTRÖM T., DE KOK T., GUIDOTTI, T. Basic Environmental Health, Oxford University Press, New York, 2001.

4. SALEM W.M., SAYED W.F., DAMARANY KH.A. Seasonal physico-chemical and microbiological pollutants of portable ground water in qena governorate, Egypt, A case study. African Journal of Environmental science and Technology. 8 (12), 730, 2014.

5. PRÜSS-USTÜN A., BARTRAM J., CLASEN T., COLFORD JR J. M., CUMMING O., CURTIS V., BONJOUR S., DANGOUR A. D., FRANCE J. D., FEWTRELL L., FREEMAN M. C., GORDON B., HUNTER P.R., JOHNSTON R.B., MATHERS C., MÄUSEZAHL D., MEDLICOTT K., NEIRA M., STOCKS M., WOLF J., CAIRNCROSS S. Burden of disease from inadequate water, sanitation and hygiene in low-and middle-income settings: a retrospective analysis of data from 145 countries. Tropical Medicine \& International Health. 19 (8), 894, 2014.

6. WHO. Drinking-water. World Health Organization fact sheets, https ://www.who.int/en/news-room/fact-sheet s/ detail 1/drinkingwater, Accessed 27 Dec 2018, 2018 a.

7. PAWARI M. J., GAWANDE S. Ground water pollution and its consequence.International536 Journal of Engineering Research and General Science 3 (4),773, 2015. 
8. PHIRI B.J., FRENCH N.P., BIGGS P.J., STEVENSON, M.A., REYNOLDS A.D., GARCIA-R J.C., HAYMAN D.T.S. Microbial contamination in drinking water at public outdoor recreation facilities in New Zealand. Journal of Applied Microbiology. 130 (1), 302, 2021.

9. DAUD M.K., NAFEES M., ALI S., RIZWAN M., BAJWA R.A., SHAKOOR M.B., ARSHAD M.U., CHATHA S.A.S., DEEBA F., MURAD W., MALOOK I., ZHU S.J. Drinking water quality status and contamination in Pakistan. BioMed research international, 2017.

10. KHAN S.S., TAREEN H., JABEEN U., MENGAL F., MASOOD Z., AHMED S., BIBI S., RIAZ M., RIZWAN S., MANDOKHAIL F., IRUM U., MENGAL R. Quality assessment of drinking water from the different colonies of Quetta city, Pak-istan according to WHO Standards,"Biological Forum: An International Journal. 7, 699, 2015

11. SHAHID N., ZIA Z., SHAHID M., FAIQ BAKHAT H., ANWAR S., MUSTAFA SHAH G., RIZWAN ASHRAF M. Assessing Drinking Water Quality in Punjab, Pakistan. Polish Journal of Environmental Studies. 24 (6), 2015.

12. UYAKA K., OZDEMIRB I. TOROZB. Seasonal variations of disinfection by-product precursors profile and their removal throughsurface water treatment plants. Science of the total environment, 390, 417, 2008

13. JOS P. The origin of speciation: Trace metal kinetics over naturalwater/sediment interface and the consequences for bioaccumulation.Environmental Pollution, 157, 519, 2009.

14. SHAREEF K.M., MUHAMAD S.G., SHEKHANI N.M. Physical and chemical status of drinking water from water treatment plants on greater Zab River. J. Appl. Sci. Environ. 13 (3), 89, 2009.

15. WORLD HEALTH ORGANIZATION (WHO). Guidelines for Drinking-water Quality FIRST ADDENDUM TO THIRD EDITION Volume 1, 2006.

16. GUPTA D., SUNITA P., SAHARAN J.P. Physiochemical analysis of ground water of selected area of Kaithal City (Haryana) India. Researcher, 1 (2), 2009.

17. AHMED J., WONG L.P., CHUA Y.P., CHANNA N., MAHAR R.B., YASMIN, A., VANDERSLICE J., GARN J.V. Quantitative microbial risk assessment of drinking water quality to predict the risk of waterborne diseases in primary-school children. International journal of environmental research and public health. 17 (8), 2774, 2020.

18. KHALIL M.A., SALEM Z.E.S., GHEDA S.F., EL-SHEEKH M.M. Quality assessment of drinking water in Tanta City, Egypt. Journal of Environmental Science and Engineering. B, 2 (5B), 257, 2013.

19. APHA. Standard methods for analysis of water and wastewater. $21^{\text {th }}$ Ed. American Public Health Association, Inc., Washington D.C.20001-3710, 2005.

20. WHO. Guidelines for Drinking Water Quality [Electronic Resource]: Fourth Edition, World Health Organization, Geneva, 541, 2011.

21. EGYPTION MINISTRY OF HEALTH STANDARDS (decision of the Minister of Health no. 458, 2007), 2007.

22. SMWW Standard Methods for the Examination of Water and Wastewater, 2005.

23. ISO / FDIS 20179. Water quality - Determination of microcystins - Method using solid phase extraction (SPE) and high performance liquid chromatography (HPLC) with ultraviolet (UV) detection, 2005.

24. THURET-BENOIST H., PALLIER V., FEUILLADECATHALIFAUD G. Quantification of microcystins in natural waters by HPLC-UV after a pre-concentration step: validation of the analytical performances and study of the interferences." Environmental toxicology and pharmacology 72, 103223, 2019.

25. WHO Annual Report WHO/UNICEF Joint Monitoring Programme (JMP) for Water Supply and Sanitation; WHO: Geneva, Switzerland, 2018 b.

26. AMIN R., ZAIDI M.B., BASHIR S., KHANANI R., NAWAZ R., ALI S., KHAN S. Microbial contamination levels in the drinking water and associated health risks in Karachi, Pakistan. Journal of Water, Sanitation and Hygiene for Development. 9 (2), 319, 2019.

27. DIRICAN S. Assessment of water quality using physicochemical parameters of Çamlıgöze Dam Lake in Sivas, Turkey. Ecologia, 5 (1), 1, 2015.

28. OMER N.H. Water quality parameters. Water QualityScience, Assessments and Policy. 18, 2019.

29. GUIDELINES FOR CANADIAN DRINKING WATER QUALITY: Guidance Document. Guidance on Monitoring the Biological Stability of Drinking Water in Distribution Systems. Consultation period ends, October 16, 2020.

30. CHAKRABARTY S., SAMARA H.P. Statistical approach to multivariate analysis of drinking water quality in Kamrup district, Assam, India, Arch. Appl. Sci. Res. 3, 258, 2011.

31. VAN BENSCHOTEN J.E., EDZWALD J.K. Measuring aluminum during water treatment: Methodology and application. JAWWA 82 (5), 71, 1990.

32. SIVARAMANAN S. Acid rain, causes, effect and control strategies. Central Environmental Authority, Battaramulla, 1, 2015.

33. M MOHAMED F., NASR EL-DEEN F., M KAMAL A. The Relationship between Algal Counting and Chemicals Consumption of Conventional Purification Systems at Qena Governorate, Egypt. Egyptian Journal of Aquatic Biology and Fisheries, 24 (1), 161, 2020.

34. EDZWALD J.K. Aluminum in drinking water: Occurrence, effects, and control. Journal-American Water Works Association, 112 (5), 34, 2020.

35. JEKEL M.R. Aluminum in water: How it can be removed? Use of aluminum salts in treatment. Proc. of the Int. Water Supply Ass., Copenhagen, Denmark, May 2531, 1991.

36. MOHAMED B.M. IBRAHIM, EMAD K. RADWAN, AHMED S. MOURSY AHMED H. BEDAIR. Humic substances as precursors for trihalomethanes yields upon chlorination, Desalination and Water Treatment, 57:55, 26494-26500, 2016. DOI: 10.1080/19443994.2016.1166460

37. AMY G.L, CHADIK P.A. CHOWDHURY Z.K. Developing models for predicting trihalomethane formation potential kinetics, JAWWA, 79 (7), 89, 1987.

38. COTRUVO J.A., AMATO H. National trends of bladder cancer and trihalomethanes in drinking water: A review and multicountry ecological study. Dose-Response, 17 (1), 1559325818807781, 2019.

39. MINNESOTA DEPARTMENT OF HEALTH (MDH). Health Risk Assessment Unit, PO Box 64975, St. Paul MN 55164, 651-201-4899, health.risk@state.mn.us, 2016.

40. ASLANI H., HOSSEINI M.S., MOHAMMADI S., NAGHAVI-BEHZAD M. Drinking Water Disinfection Byproducts and Their Carcinogenicity, A Review of Unseen Crisis. International Journal of Cancer Management. 12 (5), 2019.

41. VENGOSH A. Treatise on Geochemistry. Salinization and saline environments. $2^{\text {nd }}$ ed. Elsevier Ltd, 2014.

42. OKPOKWASILI G.C, AKUJOBI T.C. Bacteriological indicators of tropical water quality. Environmental 
Toxicology, 11, 77-81, 1996. https://doi.org/10.1002/ (SICI)1098-2256(1996)11:2<77::AID-TOX1>3.0.CO;2-5

43. HODEGKISS I.J. Bacteriological monitoring of Hong Kong marine water quality. Environment International 14, 495, 1988. https://doi.org/10.1016/0160-4120(88)90410-2

44. NICHOLSON K.N., NEUMANN K., DOWLING C., SHARMA S. E. coli and coliform bacteria as indicators for drinking water quality and handling of drinking water in the Sagarmatha National Park, Nepal. Environ Manag Sustain Dev. 6, 411, 2017.

45. KARKEY A., JOMBART T., WALKER A.W., THOMPSON C.N., TORRES A., DONGOL S., THIEU N.T.V., THANH D.P., NGOC D.T.T., VINH P. V., SINGER A.C., PARKHILL J., THWAITES G., BASNYAT B., FERGUSON N., BAKER S. The Ecological Dynamics of Fecal Contamination and Salmonella Typhi and Salmonella Paratyphi A in Municipal Kathmandu Drinking Water. PLoS Neglected Tropical Diseases, 10 (1), e0004346, 2016. https://doi.org/10.1371/journal.pntd.0004346

46. WHO, Guidelines for Drinking-water Quality (Third Edition, Vol. 1), World Health Organization, Geneva, 2001.

47. ZAMYADI A., GLOVER C.M., YASIR A., STUETZ R., NEWCOMBE G., CROSBIE N.D., LIN T., HENDERSON R. Toxic cyanobacteria in water supply systems: data analysis to map global challenges and demonstrate the benefits of multi-barrier treatment approaches. $\mathrm{H}_{2}$ Open Journal, 2021.
48. ZAMYADI A., ROMANIS C., MILLS T., NEILAN B., CHOO F., CORAL L., GALE D., NEWCOMBE G., CROSBIE N., STUETZ R., HENDERSON R. Diagnosing water treatment critical control points for cyanobacterial removal: exploring benefits ofcombined microscopy, nextgeneration sequencing, and cell integrity methods.Water Research. 152, 96, 2019.

49. SAXENA A., TIWARI A., KAUSHIK R., IQBAL H.M., PARRA-SALDÍVAR R. Diatoms recovery from wastewater: Overview from an ecological and economic perspective. Journal of Water Process Engineering, 101705, 2020.

50. SAFIYANU I., HASSAN M.I., SALE A.I., SADIQ I.Z., MARDIYYA A.Y. General review on toxic algae. International Journal of Engineering \& Scientific Research. 6 (9), 23, 2018.

51. CARMICHAEL W. The Toxins of Cyanobacteria. African Journal of Biotechnology, Scientific American Press, 3 (3), 159, 1994.

52. WHO. Safe Piped Water,Managing, Microbial Water Quality in Piped Distribution Systems, World Health Organization, Geneva, 2004.

53. TER BRAAK C.J., VERDONSCHOT P.F. Canonical correspondence analysis and related multivariate methods in aquatic ecology. Aquatic sciences. 57 (3), 255, 1995. 